\title{
What Drives Post Adoption Behavior in Virtual Traffic Community: The Role of Utilitarian and Hedonic Values
}

\section{Trang Nguyen}

Institute of International Management

National Cheng Kung University

Tainan, Taiwan

Email: trangnth@uel.edu.vn

\section{Jengchung Victor Chen}

Institute of International Management

National Cheng Kung University

Tainan, Taiwan

Email: victor@mail.ncku.edu.tw

\section{Abstract}

This study examines how satisfied experience enhance continuance intention of travel and navigation mobile application through the perceived value. It is proposed that user satisfaction stems from both utilitarian and hedonic value. Using a sample of 241 respondents and structural equation modeling, this study confirms that all aspect of perceived quality (information, system, service) enhances the perceived functionality of the app, while the sociability is the main determinant of the enjoyment perception. Both utilitarian and hedonic value are crucial in driving satisfaction, and eventually continuance intention of the apps. The findings are translated into practical implications and revenues for future research.

Keywords Perceived utilitarian value, Perceived hedonic value, Sociability, Continue to use 


\section{Introduction}

The advanced technology allows the popularity and growth of virtual platforms with easy access and participation (Lu \& Yang, 2011), for instance SNSs as Twitter, Facebook, Wikis, Blogs, forums, news group etc, where people meet online to share, communicate and exchange information with others. In addition, the Internet available with the ubiquitous mobile devices facilitate an active, updated and informative virtual communities, (Lu \& Yang, 2011; Zheng, Zhao, \& Stylianou, 2013). The benefits obtained from the use of virtual communities with millions of users is obvious in economic marketing and social and educational perspectives (Chiu, Hsu, \& Wang, 2006). One instance relates to the Usergenerated content in traffic navigation purpose. Importantly, as complex and burdened traffic congestion is increasing, technology is expected to offer smarter solution to traffic and transportation services and solve the extreme loss of productivity caused by the traffic congestion (Heiskala, Jokinen, \& Tinnilä, 2016). Therefore, digitalized traffic and transportation has been increasingly concerned as solution to these issues by the application of sensor and connectivity technology to roads and traffic lights, making it smarter compared to the traditional infrastructure. In addition, unlike the traditional one-way and passive communication, commuters switched to two-way communication in which both the providers and the audiences or users has become useful sources of information (Olsen, 2014) and effectively connect individuals with mutual goals to exchange benefits in virtual communities.

It is obvious that the widespread use of social media is not only by big IT names like Google but also new agencies with good reputation to build relationship and keep in touch with the customers and audiences. Moreover, audiences are even promoted to share news they have missed, which indicates the desire to let customers continue using, eventually, become more loyal to service providers (Olsen, 2014). Ma and Agarwal (2007) agreed that just a few virtual platforms successfully achieve users' continuance intention while many are losing their members. One of the possible reasons is the information insufficiency on virtual communities that makes it hard to retain users as the information quality can enhance the value of the virtual communities (Butler, 2001; Gu, Konana, Rajagopalan, \& Chen, 2007). Besides, individuals use and share information through their devices and application. As such, system quality (e.g. ease of use) plays an important role in making users to feel more engaged and enjoyable in the interaction (Zheng et al., 2013). Prior research have confirmed the importance of both information quality and system quality in user satisfaction (H. F. Lin (2008),. Another important determinant for user continuance usage relates to service quality, according to (Delone \& McLean, 2003; Xu, Benbasat, \& Cenfetelli, 2013).

Despite the important role, the factor of quality may not be able to fully explain user continuance intention to use. Social interaction is also regarded as an essential element to engage members together. Being technologically sociable is no longer a new concept under the boom of technological development. The ongoing and advanced technologies offer platforms where users can engage, interact, and socialize with others. Accordingly, the concept of sociability would be introduced in this study as a human's want and need to socialize with peers via technology usage. Socializing with others is considered intrinsic need of human beings (e.g., Biocca, Harms, and Gregg (2001); Biocca, Harms, and Burgoon (2003)). Some efforts have been made to find out the significance of hedonic values and pleasure in getting individual motivated to use the IS (e.g., Van der Heijden (2004); Igbaria, Parasuraman, and Baroudi (1996); Agarwal and Karahanna (2000); Venkatesh and Davis (2000)) regardless the efficiency and effectiveness gains of this hedonic value is unlikely to be measured (Brown \& Bell, 2006). Accordingly, the reasons for individuals to use an IS are no longer purely for its utility value, or ease of use value but also for the enjoyment obtained from the interaction with strangers that we can relate to in some way.

Therefore, this research aims to investigate what factors influence the continuance intention to use in traffic information virtual community which has been neglected by researchers. To our best understanding, much attention has been paid to understand the effort to improve travelers' performance but not at the successful factors for the performance of those applications.

\section{Theoretical Background and Research Context}

\subsection{IS Success Model}

Based on the idea of information influence theory by Mason (R. O. Mason, 1978) combined with Shannon and Weaver's work (Shannon \& Weaver, 1949), six dimensions for IS success model was proposed by DeLone and Mc Lean including system quality, information quality, system use, user satisfaction, individual impact, and organizational impact (DeLone \& McLean, 1992). This model has attracted several modifications from other researchers such as Pitt et al (Pitt, Watson, \& Kavan, 1995), which refers to the activity of measuring the information received by users as well as the service quality 
offered by employees through the use of IS (R. O. Mason (1978),Kettinger and Lee (1994)). Based on this idea, DeLone and McLean (Delone \& McLean, 2003) added "service quality" dimension and further extended the application of IS success model to web applications, which is featured by another so-called "net benefits" dimension as a result of joining the effect of both individual and organizations. In another modification effort, "intention to use" has been added to generate an updated six-dimension model and the application was widened to Internet area as well. The definition of each dimension is summarized as table below.

\begin{tabular}{ll}
\hline System quality & $\begin{array}{l}\text { Definition } \\
\text { The expected quality feature regarding how available, usable and reliable a } \\
\text { web-based environment is. }\end{array}$ \\
\hline Information quality & $\begin{array}{l}\text { A measurement of how complete, personalized, and relevant a web-based } \\
\text { environment is. }\end{array}$ \\
\hline Service quality & $\begin{array}{l}\text { A measurement of how assurable, responsive, empathetic and dependent } \\
\text { a web-based environment provided by the IT units or outsourced to service } \\
\text { providers is }\end{array}$ \\
\hline User satisfaction & A reaction to the use of system output. \\
\hline Intention to use” & $\begin{array}{l}\text { An attitude," is a system phenomenon-related behavior, including the } \\
\text { nature, level, appropriateness, and frequency of use. }\end{array}$ \\
\hline Net benefits & $\begin{array}{l}\text { A measurement of success in capturing the combined results of both good } \\
\text { and bad effect of the system. }\end{array}$ \\
\hline
\end{tabular}

Table 1: IS success model dimensions definition

According to DeLone and McLean, how a user employs a system and their satisfaction is affected by the quality of the system, the information provided and the service. If a user gets more satisfied with a system, they are understandably to have higher intention to use, which eventually affect the actual use. Moreover, net benefits are also found to be varied under the effect of system use and user satisfaction. In summary, prior researches have applied the updated IS success model proposed by DeLone and McLean's to deal with health IT implementation, to conceptualize and empirically examine important model antecedents or constructs, system quality, information quality, and service quality ( $\mathrm{Yu}$ Su, Than Win, Fulcher, and Chia Chiu (2009), Lau, Price, and Keshavjee (2011), Bossen, Jensen, and Udsen (2013), Akter, D’Ambra, and Ray (2013)).

\subsection{Sociability}

Sociability refers to the level at which social interactions and social connectivity (Gao, Dai, Fan, \& Kang, 2010) that are promoted and supported by the communication environment including the goals of social interaction shared among group members (Preece, 2000). The emphasis of Sociability is on members' organization of social practices and construction of their identity (Phang, Kankanhalli, \& Sabherwal, 2009). Simmel (Simmel (1910);Simmel and Hughes (1949)) demonstrates sociability relates to how people develop a tendency to associate with others and he assigned sociability as a non-utilitarian purpose. The association can appear in many forms but share the common feature characterized by a feeling of togetherness and union with others and by a satisfaction for that feeling (p. 254). For instance, in "sociological play-form" (p. 258), sociability is determined by the joy of others (p. 257 It could directs a person to deliver as many sociable values to other people as the reciprocal values he/ she obtains from these individuals during their interaction. In other words, sociability illustrates how an individual is inspired or desire to search for being accompanied by others have experience with joys and pleasure. Hence, sociability describes how a user look for the company of the others in the platform or community to get pleasurable experience in return. Evolving from this idea, we argue "sociability" as an additional element that is defined as users' need to socialize and could be met through the connectivity and interaction with others in a system.

The determinants for users' perception of the sociability of social software have been discussed in prior study. This research adopts the sociability concept including four dimensions social presence, social benefit, social support, and self-presentation from Gao et al (Gao et al., 2010). Social presence represents how a user perceive about the platform (Kreijns, Kirschner, \& Jochems, 2003). In this sense, social presence is conceptualized as the extent to which a user is perceived as a "real person" in mediated communication (Park \& Cameron, 2014). Social benefit is employed to indicate the mental benefits and goals gained thanks to using social commerce sites such as the emotional bonding of liking or the feeling of being close or intimate or tolerate with others' mistakes or the feeling of familiarity shared between social network friends. Meanwhile social support refers to the facilitation gained from social interactions (Lee \& Kwon, 2011). In other words, it indicates how an individual is aware of gaining the care, support and response from other members in the social group such as informational support and emotional 
support (Hajli (2014),Shanmugam, Sun, Amidi, Khani, and Khani (2016)). Finally, self-presentation describes the means to express a customer's self and how he/she seeks for supporting responses from other members through traffic community.

\subsection{Waze}

Waze is known as an application for community-based traffic and navigation, with about 90 million active users worldwide, targeting at serving mainly car and motorcycle drivers. Founded by Ehud Shabtai in 2008 and acquired by Google in 2013, Waze visions that other than any sources of information, information from people is the best channel that can help their peers to correct information on traffic map as people's purpose is to sort out the most effective way to get to their destination in the shortest time expected. Therefore, Waze believe that people can provide real-time information to other users, and take use of this information source to automatically redirect users to ensure on-time schedule through other user's recent experience and report'․

\section{Hypothesis Development}

\subsection{Information Quality, System Quality and Service Quality and Perceived Utilitarian Value}

Information quality refers to the desired characteristics of the technological outputs (Petter, DeLone, \& McLean, 2008; Petter \& McLean, 2009). In different settings, the desired characteristics of information can differ. Gu et al. (2007) suggest that low-quality information increases users' efforts for seeking and processing information. Good-quality information can lead to the efficiency. For traffic information, it is essential for users to have an up-to-date, accurate, complete information for the effectiveness of decision making. Moreover, the information must be what they truly need and presented in an easy-tounderstand format because they may not have much time when they are on the roads and have to make a quick decision due to the available information at that time

System quality refers to the performance of IS measurements can vary in different online settings. Markus (2005) suggests that the IS features are important to facilitate user interaction and subsequently result in its success. The system should be designed for users to access information and participate in the virtual communities effectively (Blanchard, 2008). In addition, it is fundamental for virtual communities to offer a well-organized and understandable navigation system so that users can perform their participation or usage effectively and efficiently (Gu et al., 2007). Moreover, system quality not only facilitates the usage of consuming and providing information, but also leads to the desired performance (Zheng et al., 2013).

Service Quality is an additional construct in the updated IS success model. The service in the model refers to the service that users receive from IS departments or IS system support service. After the growth of web 2.0 systems, service quality has become very important to various IS contexts e.g. ecommerce (Scott, DeLone, \& Golden, 2011, June). In the recent study of Petter, DeLone, and McLean (2013), responsiveness and empathy are found to be the most important aspects to consumers/users when they look for assistance from the IS support teams.

Perceived value is generally conceptualized as the customer's or users' overall evaluation of what they consume upon give and take logical sense. (Zeithaml, 1988). Therefore, it is the perceived difference between what users give and what they receive (benefit and cost). This would apply to any context including the traffic information virtual communities in which the benefit is all the quality users receive from the platform and cost is considered as time and effort they spend in such a platform. Previous research state that perceived quality is a direct antecedent of perceived value (Teas \& Agarwal, 2000) in which consequently affect the intention to reuse or repurchase (Cronin Jr, Brady, \& Hult, 2000; Patterson \& Spreng, 1997). Similarly, perceived value has also been proved to affect the customer loyalty, e.g. Dodds, Monroe, and Grewal (1991); Grewal, Monroe, and Krishnan (1998); Parasuraman and Grewal (2000). The quality-value-loyalty chain has been tested in many consumer behavior studies e.g. Durvasula, Lysonski, Mehta, and Tang (2004); Patterson and Spreng (1997); Zeithaml (1988) Dlačić, Arslanagić, Kadić-Maglajlić, Marković, and Raspor (2014). and IS studies e.g. Y. S. Wang (2008).

Under social virtual setting, perceived values include 3 values: utilitarian value which is expressed by how users cognitively evaluate the utility feature of a virtual community especially regarding needmeeting and problem-solving (Babin, Darden, \& Griffin, 1994). Accordingly, we argue that the

\footnotetext{
${ }^{1}$ https://www.waze.com
} 
information, system and service reflect the utility of the traffic information virtual community platforms to form the hypotheses as below:

H1. Information quality positively influences perceived utilitarian value.

H2. System quality positively influences perceived utilitarian value.

H3. Service quality positively influences perceived utilitarian value

\subsection{Sociability and Perceived Hedonic Value}

As mentioned above, sociability has been argued to represent a "play-form" (Simmel and Hughes (1949), p. 258) of users as their satisfied experiences are linked with the relationship with other peers. Previous studies also mention predecessors of enjoyment (i.e. the extent to which a user perceive the system usage as fun ) includes attached feeling, motivation for serving their general prosperity (Leary and Baumeister (2000), Lou, Chau, and Li (2005)), relationship commitment, perceived critical mass (Lou et al., 2005), flow, arousal (L. C. Wang, Baker, Wagner, \& Wakefield, 2007), and social norms and curiosity (Rouibah, 2008). It is understandable that the behaviors of sharing and exchanging feeling and thoughts can lead to a more enjoyable experience. Moreover, if negative feeling such as worries, concerns, stress, and anxieties, are shared and released, positive emotion can be developed (Leary \& Baumeister, 2000). Similar rule applies to relationship commitment or the ambition to be a part of a relationship (Lou et al., 2005).In short, pleasure sharing among others can generate the "true pleasure" from behavioral performance per se, which allows us to hypothesize as:

H4. Sociability influences positively perceived hedonic value

\subsection{Perceived Utilitarian Value, Perceived Hedonic and Satisfaction}

Within this study scope, we view perceived value as a primarily cognitive variable, emphasizing the distinction between get and give elements whereas satisfaction is treated as an affective construct. There is a strong support for the antecedent relationship between Perceived value and users' satisfaction(Tam, 2004) as well as that in virtual communities. (Eggert \& Ulaga, 2002; Lin \& Wang, 2006; Y. S. Wang, 2008; Yang \& Peterson, 2004). Consequently, it is reasonable to conclude that perceived value of using traffic information virtual communities can result in user satisfaction.

Further, the virtual community platform does not only offer the utilitarian value but also hedonic value through the enjoyable feeling users get from interaction with the platform. Hedonic value refers to the fun and relaxing feeling or good emotions generated through joyful experience of an action for its own sake, (Babin et al., 1994). It is found that hedonic value makes users feel satisfied under different contexts, particularly in online platform where the border between functionality and enjoyment cannot be clearly defined (Chea \& Luo, 2008). As supported by (Stafford, Stafford, \& Schkade, 2004), the satisfaction of users of online platform or in virtual world can be generated thanks to the hedonic value (Verhagen, Feldberg, van den Hooff, Meents, \& Merikivi, 2011). Thus, we hypothesize as:

$\mathrm{H}_{5}$. Perceived utilitarian value positively influences user satisfaction.

H6. Perceived hedonic value positively influences user satisfaction.

\subsection{User Satisfaction and Continuous Usage}

User satisfaction is defined as a certain state of emotion and psychology created after the experience with an IS. As discussed in both IS and Marketing literature, satisfaction refers to is an effusive reaction that are able to predict continuance and repurchase intention (Bhattacherjee, 2001; Chea \& Luo, 2008; McKinney, Yoon, \& Zahedi, 2002; Oliver, 1994), These intentions are critical to the success for virtual communities (Blanchard, 2008). If user satisfaction is not kept up, they tend to lose the connection with the platform and develop the intention to discontinue the usage or replace by another virtual platform for more informative and beneficial results (Gu et al., 2007). As a result, we form Hypothesis 7 as:

H7. User satisfaction positively influences continuance usage 


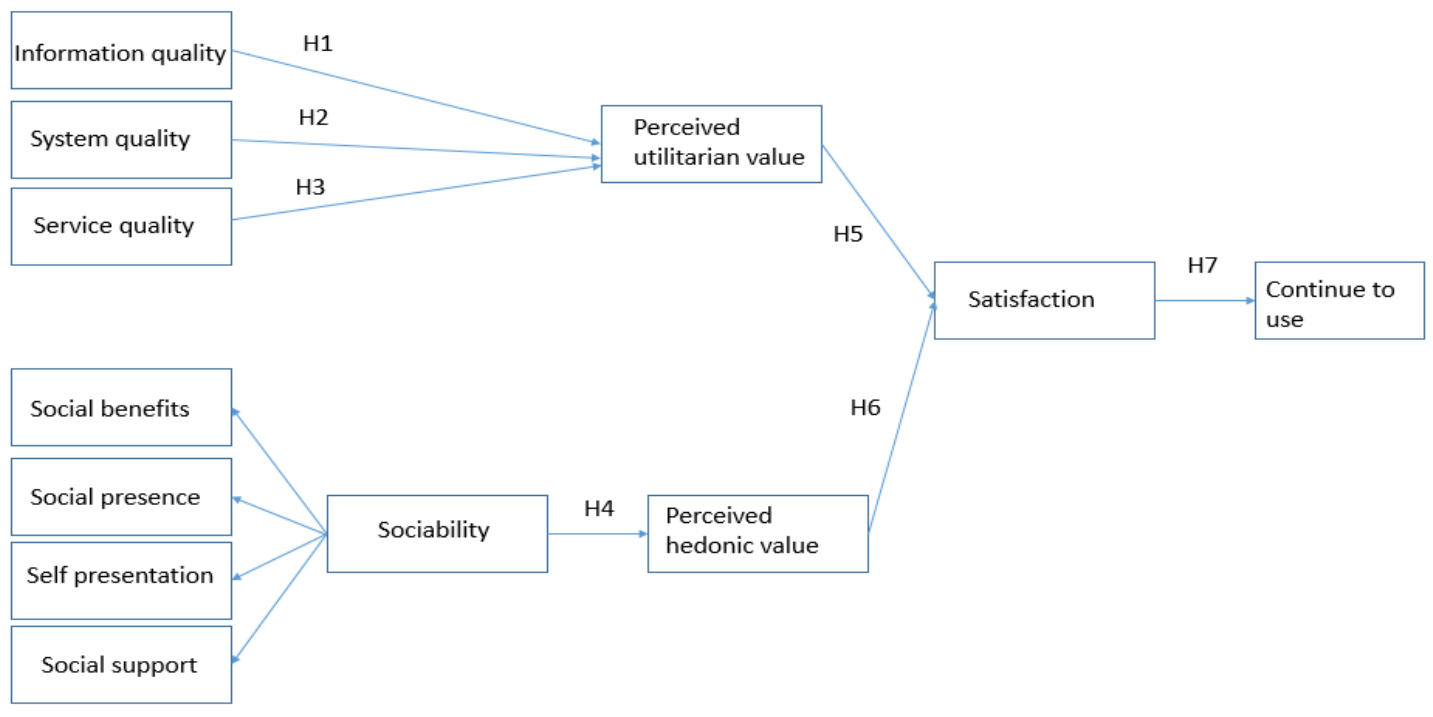

Figure 1: Research model

\section{Research Methodology}

\subsection{Data Collection}

The survey questionnaire was collected from Waze users in United State through Amazon M-Turk which is a reliable source of participants for academic research (W. Mason \& Suri, 2012; Sprouse, 2011). After screening unusual and unengaged responses, a total number of respondents are 241 with 122 Male (50.6\%) and 119 Female (49.4\%). Among this group of participants, 56\% are between 25 and 35 years old and $49.4 \%$ users holding a bachelor degree.

\subsection{Measures}

The questionnaire uses a 7 point Likert scale, with 1 for "strongly disagree" and 7 for "strongly agree." Information Quality items are adapted from the study of (H.-F. Lin, 2008), System Quality items are adopted from (Liang, Ho, Li, \& Turban, 2011); (H.-F. Lin, 2008); (Y. S. Wang, 2008), Service Quality items are specifically adopted from W.-T. Wang, Wang, \& Liu, 2016, Perceived Utilitarian Value items are adapted from (Parasuraman, Zeithaml, \& Malhotra, 2005); (Zhou, Fang, Vogel, Jin, \& Zhang, 2012), Social presence items are adapted from Animesh et al. (Animesh, Pinsonneault, Yang, \& Oh, 2011), Social support items are based on Liang et al.'s (Liang et al., 2011) study, Social benefit six items are adapted from $\mathrm{Ng}(\mathrm{Ng}, 2013)$ and Lee and Kwon (Lee \& Kwon, 2011), Self-representation items are adapted from Seidman (Seidman, 2013) and Shin and Kim (Shin \& Kim, 2010), Perceived Hedonic Value items are adopted from Zhou et al. (2012), Van der Heijden (2004), User Satisfaction are adapted from H. F. Lin (2008); Y. S. Wang (2008); Zheng et al. (2013)

\section{Data Analysis}

\subsection{Factorial Validity and Reliability}

\begin{tabular}{llll}
\hline \multicolumn{1}{c}{ Construct } & CA & CR & AVE \\
\hline Information quality & 0.883 & 0.915 & 0.682 \\
\hline System quality & 0.895 & 0.919 & 0.656 \\
\hline Service value & 0.887 & 0.917 & 0.689 \\
\hline $\begin{array}{l}\text { Perceived utilitariann } \\
\text { value }\end{array}$ & 0.878 & 0.917 & 0.733 \\
\hline Social presence & 0.910 & 0.937 & 0.787 \\
\hline Social benefit & 0.931 & 0.948 & 0.784 \\
\hline Self-presentation & 0.938 & 0.953 & 0.803 \\
\hline Social support & 0.919 & 0.939 & 0.755 \\
\hline
\end{tabular}




\begin{tabular}{llll}
\hline Perceived hedonic value & 0.938 & 0.951 & 0.765 \\
\hline Satisfaction & 0.864 & 0.907 & 0.710 \\
\hline Continue to use & 0.879 & 0.925 & 0.805
\end{tabular}

Table 2. Cronbach's alpha, Composite reliability, and AVE scores of major constructs

To test he reliability of instrument, Cronbach's alpha and composite reliability are examined. As shown in Table 2, those two value are all above the criteria of 0.7.

Factorial validity is established by convergent validity and discriminant validity. Convergent validity is examined based on item loadings and the average variance extracted (AVE). The results indicate that most loadings are greater than the minimum value of 0.70 ( $\mathrm{SS} 1$ is the only item to be removed as its loading is lower than the required threshold). In addition, the Average Variance Extracted (AVE) are also higher than the threshold of 0.5. The first order factors also have sufficient loading to the second factor, i.e. sociability. To examine if there is a threat from multi-collinearity, the variance inflation factor (VIF) statistic was computed. The result shows that none of the VIF values were greater than the benchmark of 3.33. Hence, multi-collinearity is not an issue in this study.

In addition to this, discriminant validity is assessed to test if two constructs are distinct constructs. The table 3 shows that square root of the AVEs are greater than the correlations among the constructs, so we can conclude that the discriminant validity is satisfactory (Fornell \& Larcker, 1981)

\begin{tabular}{|c|c|c|c|c|c|c|c|c|c|c|c|c|c|}
\hline & Mean & $S D$ & CON & $I Q$ & $P H V$ & PUV & $\boldsymbol{S A T}$ & $\boldsymbol{S B}$ & $S E$ & $S Y Q$ & $\boldsymbol{S P}$ & SPR & $S S$ \\
\hline$C O N$ & 5.520 & 1.288 & 0.897 & & & & & & & & & & \\
\hline$I Q$ & $5 \cdot 386$ & 1.023 & 0.693 & 0.826 & & & & & & & & & \\
\hline$P H V$ & 4.590 & 1.459 & 0.342 & 0.390 & 0.875 & & & & & & & & \\
\hline$P U V$ & 5.430 & 1.106 & 0.747 & 0.832 & 0.410 & 0.856 & & & & & & & \\
\hline$S A T$ & 5.216 & 1.167 & 0.760 & 0.728 & 0.562 & 0.774 & 0.843 & & & & & & \\
\hline$S B$ & 4.243 & 1.637 & 0.235 & 0.270 & 0.769 & 0.302 & 0.411 & 0.885 & & & & & \\
\hline$S E$ & 4.970 & 1.122 & 0.550 & 0.676 & 0.600 & 0.702 & 0.685 & 0.567 & 0.830 & & & & \\
\hline$S Y Q$ & 5.533 & 0.974 & 0.659 & 0.754 & 0.345 & 0.750 & 0.655 & 0.226 & 0.586 & 0.810 & & & \\
\hline$S P$ & 5.430 & 1.106 & 0.354 & 0.437 & 0.725 & 0.443 & 0.522 & 0.723 & 0.607 & 0.380 & 0.887 & & \\
\hline$S P R$ & 3.801 & 1.779 & 0.161 & 0.170 & 0.753 & 0.165 & 0.370 & 0.830 & 0.510 & 0.119 & 0.624 & 0.896 & \\
\hline$S S$ & 4.773 & 1.318 & 0.309 & 0.397 & 0.742 & 0.404 & 0.469 & 0.796 & 0.626 & 0.340 & 0.784 & 0.687 & 0.869 \\
\hline
\end{tabular}

Table 3. Measurement model statistics

\subsection{Hypothesis Testing}

Table 4 presents the results of the structural model estimation by using bootstrapping procedure to test the significance of all paths. As shown in Table 4, all proposed hypotheses in the research model were found to be supported. More specifically, Information quality, system quality and service quality were found to have a positive effect on perceived utilitarian value with statistical significance at the $p<.001$ level; rendering supports for $\mathrm{H}_{1}, \mathrm{H} 2, \mathrm{H}_{3}$.

The significant positive effect of sociability on perceived hedonic value supports $\mathrm{H} 4$. In addition, both perceived utilitarian and perceived hedonic value positively affects satisfaction, supporting $\mathrm{H} 5, \mathrm{H} 6$. Finally, the paths from satisfaction to continue to use is also found to be significant as hypothesized, supporting supports $\mathrm{H}_{7}$.

\begin{tabular}{|c|c|c|c|c|c|}
\hline Hypothesis & Path & Path coefficient & T-value & P Values & $\begin{array}{l}\text { Hypothesis } \\
\text { testing }\end{array}$ \\
\hline$H 1$ & $I Q->P U V$ & 0.496 & 6.568 & 0.000 & Supported \\
\hline H2 & $S Y Q->P U V$ & 0.245 & 3.809 & 0.000 & Supported \\
\hline$H_{3}$ & $S E->P U V$ & 0.223 & 3.760 & 0.000 & Supported \\
\hline $\mathrm{H}_{4}$ & $S O C->P H V$ & 0.832 & 35.680 & 0.000 & Supported \\
\hline$H_{5}$ & $P U V->S A T$ & 0.654 & 14.433 & 0.000 & Supported \\
\hline
\end{tabular}




\begin{tabular}{llllll}
\hline$H 6$ & $P H V->S A T$ & 0.294 & 6.076 & 0.000 & Supported \\
\hline$H 7$ & $S A T->C O N$ & 0.760 & 21.646 & 0.000 & Supported \\
\hline
\end{tabular}

Table 4. Summary of hypothesis testing

\section{Discussion and Implications}

\subsection{Discussion of Findings}

This research examined the factors that influences continuous behavior in virtual traffic communities from both perceived utilitarian and hedonic value perspective. The first three hypotheses ( $\left.\mathrm{H}_{1}, \mathrm{H}_{2}, \mathrm{H}_{3}\right)$ present the effects of information quality, system quality and service quality on perceived utilitarian value. All three hypotheses are supported. In the context of this research, people take advantage of traffic app to access for the traffic information for their daily travelling. Hence, offering up to date and accurate information is an essential criterion to retain and enhance users' perceived value. In other words, the higher level of information quality, the more functional values are perceived by users. Regarding to system quality, the stability and ease-of-use facilitate user's interaction with the app, thus resulting in higher perceived usefulness toward the system. Service quality refers to the responsiveness and empathy of supporting teams to users when necessary. If The system can give more attention to individual user and offering timely assistance, it will surely enhance their perception on perceive utilitarian value.

With respect to the perceived hedonic value, sociability and its dimensions are explored. The results show that those indicators are the reflection of sociability and they positively impact perceived hedonic value. In particular, these affordances include: social presence, social benefits, self-presentation and social support. As the results present, maximizing each of the four antecedents can increase perceived hedonic value. This is consistent with theoretical arguments in which individuals desire to seek out the company of others to have pleasurable social experiences. Subsequently, a system that could facilitate social interaction is more likely evoke intrinsic value to users.

Finally, both perceived utilitarian and hedonic value significantly increase continuance behavior. This could be explained since the ongoing and advanced technologies tend to offer platforms where users can get both functional benefits and social benefits. By doing so, users are encouraged to continue usage since they could accomplish their desire to capture traffic information as well as get more fun and joyful moments.

\subsection{Theoretical Contributions}

This research contributes to the continuance behavior literature by integrating both utilitarian and social- hedonic perspective in the case of traffic information virtual communities, which have not been widely researched. The hypotheses testing help enhances the existing knowledge by extending the post adoption behavior's antecedents in hedonic and utilitarian components.

\subsection{Managerial Implications}

For managerial perspective, the results can capture what users actually value the most for their usage continuance. This will help management to consider what to emphasize and improve to retain their users. In order to retain users, it is really important to understand what brings users to the community and be in their top-of-mind position. The findings show what are the values affecting users' usage continuance. This will benefit management to develop the business strategy to enhance and retain users. In order to do this, maximizing the functional benefits as the core value and facilitating attractive social interacting environment will bring users to the community and make the traffic information platform more competitive.

\subsection{Limitations and Future Research}

This research is limited by data collection method. The data was collect from those Waze's users in the US only. This way could limit generalizability of the findings to other groups of users from other countries. Moreover, this research adapts the definition of sociability from (reference) which could be bias since there are many components affecting sociability such as activity support, context support (ref). Hence, the future research should address this gap by investigating deeply on the concept sociability. The continuance behavior in this research is still general since users using virtual communities for different purposes such as sharing information or consuming information only. Therefore, the continuance behavior could be divided as providing and consuming. These types of post adoption behavior may be another issue for future studies to consider. 


\section{References}

Agarwal, R., \& Karahanna, E. (2000). Time flies when you're having fun: Cognitive absorption and beliefs about information technology usage. MIS quarterly, 665-694.

Akter, S., D’Ambra, J., \& Ray, P. (2013). Development and validation of an instrument to measure user perceived service quality of mHealth. Information \& Management, 5o(4), 181-195.

Animesh, A., Pinsonneault, A., Yang, S.-B., \& Oh, W. (2011). An odyssey into virtual worlds: exploring the impacts of technological and spatial environments on intention to purchase virtual products. MIS quarterly, 789-810.

Babin, B. J., Darden, W. R., \& Griffin, M. (1994). Work and/or fun: measuring hedonic and utilitarian shopping value. Journal of consumer research, 20(4), 644-656.

Bhattacherjee, A. (2001). Understanding information systems continuance: An expectationconfirmation model. MIS quarterly, 12(3), 351-370.

Biocca, F., Harms, C., \& Burgoon, J. K. (2003). Toward a more robust theory and measure of social presence: Review and suggested criteria. Presence: Teleoperators \& virtual environments, 12(5), 456-480.

Biocca, F., Harms, C., \& Gregg, J. (2001). The networked minds measure of social presence: Pilot test of the factor structure and concurrent validity. Paper presented at the 4 th annual international workshop on presence, Philadelphia, PA.

Blanchard, A. L. (2008). The Encyclopedia of e-Collaboration. New York: Information Science Reference.

Bossen, C., Jensen, L. G., \& Udsen, F. W. (2013). Evaluation of a comprehensive EHR based on the DeLone and McLean model for IS success: approach, results, and success factors. International journal of medical informatics, 82(10), 940-953.

Brown, B., \& Bell, M. (2006). Play and sociability in there: Some lessons from online games for collaborative virtual environments Avatars at work and play (pp. 227-245): Springer.

Butler, B. S. (2001). Membership size, communication activity, and sustainability: A resource-based model of online social structures. Information Systems Research, 12(4), 346-362.

Chea, S., \& Luo, M. M. (2008). Post-adoption behaviors of e-service customers: The interplay of cognition and emotion. International Journal of Electronic Commerce, 12(3), 29-56.

Chiu, C.-M., Hsu, M.-H., \& Wang, E. T. (2006). Understanding knowledge sharing in virtual communities: An integration of social capital and social cognitive theories. Decision Support Systems, 42(3), 1872-1888.

Cronin Jr, J. J., Brady, M. K., \& Hult, G. T. M. (2000). Assessing the effects of quality, value, and customer satisfaction on consumer behavioral intentions in service environments. Journal of retailing, 76(2), 193-218.

DeLone, W. H., \& McLean, E. R. (1992). Information systems success: The quest for the dependent variable. Information systems research, 3(1), 60-95.

Delone, W. H., \& McLean, E. R. (2003). The DeLone and McLean model of information systems success: a ten-year update. Journal of Management Information Systems, 19(4), 9-30.

Dlačić, J., Arslanagić, M., Kadić-Maglajlić, S., Marković, S., \& Raspor, S. (2014). Exploring perceived service quality, perceived value, and repurchase intention in higher education using structural equation modelling. Total Quality Management \& Business Excellence, 25(1-2), 141-157.

Dodds, W. B., Monroe, K. B., \& Grewal, D. (1991). Effects of price, brand, and store information on buyers' product evaluations. Journal of Marketing Research, 28(3), 307-319.

Durvasula, S., Lysonski, S., Mehta, S. C., \& Tang, B. P. (2004). Forging relationships with services: The antecedents that have an impact on behavioural outcomes in the life insurance industry. Journal of Financial Services Marketing, 8(4), 314-326.

Eggert, A., \& Ulaga, W. (2002). Customer perceived value: a substitute for satisfaction in business markets? Journal of Business \& industrial marketing, 17(2/3), 107-118.

Fornell, C., \& Larcker, D. F. (1981). Structural equation models with unobservable variables and measurement error: Algebra and statistics. Journal of marketing research, 382-388.

Gao, Q., Dai, Y., Fan, Z., \& Kang, R. (2010). Understanding factors affecting perceived sociability of social software. Computers in Human Behavior, 26(6), 1846-1861.

Grewal, D., Monroe, K. B., \& Krishnan, R. (1998). The effects of price-comparison advertising on buyers' perceptions of acquisition value, transaction value, and behavioral intentions. The journal of marketing, 62(2), 46-59.

Gu, B., Konana, P., Rajagopalan, B., \& Chen, H.-W. M. (2007). Competition among virtual communities and user valuation: The case of investing-related communities. Information systems research, 18(1), 68-85. 
Hajli, M. N. (2014). The role of social support on relationship quality and social commerce. Technological Forecasting and Social Change, 87, 17-27.

Heiskala, M., Jokinen, J.-P., \& Tinnilä, M. (2016). Crowdsensing-based transportation services-An analysis from business model and sustainability viewpoints. Research in Transportation Business \& Management, 18, 38-48.

Igbaria, M., Parasuraman, S., \& Baroudi, J. J. (1996). A motivational model of microcomputer usage. Journal of Management Information Systems, 13(1), 127-143.

Kettinger, W. J., \& Lee, C. C. (1994). Perceived service quality and user satisfaction with the information services function. Decision sciences, 25(5-6), 737-766.

Kreijns, K., Kirschner, P. A., \& Jochems, W. (2003). Identifying the pitfalls for social interaction in computer-supported collaborative learning environments: a review of the research. Computers in Human Behavior, 19(3), 335-353.

Lau, F., Price, M., \& Keshavjee, K. (2011). Making sense of health information system success in Canada. Healthc Q, 14(1), 39-46.

Leary, M. R., \& Baumeister, R. F. (2000). The nature and function of self-esteem: Sociometer theory Advances in experimental social psychology (Vol. 32, pp. 1-62): Elsevier.

Lee, Y., \& Kwon, O. (2011). Intimacy, familiarity and continuance intention: An extended expectationconfirmation model in web-based services. Electronic Commerce Research and Applications, $10(3), 342-357$.

Liang, T.-P., Ho, Y.-T., Li, Y.-W., \& Turban, E. (2011). What drives social commerce: The role of social support and relationship quality. International Journal of electronic commerce, 16(2), 69-90.

Lin, H.-F. (2008). Determinants of successful virtual communities: Contributions from system characteristics and social factors. Information \& Management, 45(8), 522-527.

Lin, H.-H., \& Wang, Y.-S. (2006). An examination of the determinants of customer loyalty in mobile commerce contexts. Information \& Management, 43(3), 271-282.

Lin, H. F. (2008). Determinants of successful virtual communities: Contributions from system characteristics and social factors. Information \& Management, 45(8), 522-527.

Lou, H., Chau, P. Y., \& Li, D. (2005). Understanding individual adoption of instant messaging: An empirical investigation. Journal of the Association for Information Systems, 6(4), 5.

Lu, Y., \& Yang, D. (2011). Information exchange in virtual communities under extreme disaster conditions. Decision Support Systems, 5o(2), 529-538.

Ma, M., \& Agarwal, R. (2007). Through a glass darkly: Information technology design, identity verification, and knowledge contribution in online communities. Information Systems Research, 18(1), 42-67.

Markus, M. L. (2005). Technology-shaping effects of e-collaboration technologies: Bugs and features. International Journal of e-Collaboration, 1(1), 1-23.

Mason, R. O. (1978). Measuring information output: A communication systems approach. Information \& Management, 1(4), 219-234.

Mason, W., \& Suri, S. (2012). Conducting behavioral research on Amazon's Mechanical Turk. Behavior research methods, 44(1), 1-23.

McKinney, V., Yoon, K., \& Zahedi, F. M. (2002). The measurement of web-customer satisfaction: An expectation and disconfirmation approach. Information Systems Research, 13(3), 296-315.

Ng, C. S.-P. (2013). Intention to purchase on social commerce websites across cultures: A cross-regional study. Information \& Management, 5o(8), 609-620.

Oliver, R. L. (1994). Conceptual issues in the structural analysis of consumption emotion, satisfaction, and quality: Evidence in a service setting. Advance in Consumer Research, 21(0), 16-22.

Olsen, N. C. (2014). The social news system: Examining the relationship between psychological sense of community, social network site use, and news sharing behaviors. (Doctoral Dissertation), University of Minnesota, Minnesota.

Parasuraman, A., \& Grewal, D. (2000). The impact of technology on the quality-value-loyalty chain: a research agenda. Journal of the academy of marketing science, 28(1), 168-174.

Parasuraman, A., Zeithaml, V. A., \& Malhotra, A. (2005). ES-QUAL: A multiple-item scale for assessing electronic service quality. Journal of service research, 7(3), 213-233.

Park, H., \& Cameron, G. T. (2014). Keeping it real: Exploring the roles of conversational human voice and source credibility in crisis communication via blogs. Journalism \& Mass Communication Quarterly, 91(3), 487-507.

Patterson, P. G., \& Spreng, R. A. (1997). Modelling the relationship between perceived value, satisfaction and repurchase intentions in a business-to-business, services context: An empirical examination. International Journal of service Industry management, 8(5), 414-434. 
Petter, S., DeLone, W., \& McLean, E. (2008). Measuring information systems success: models, dimensions, measures, and interrelationships. European journal of information systems, 17(3), 236-263.

Petter, S., DeLone, W., \& McLean, E. R. (2013). Information systems success: The quest for the independent variables. Journal of Management Information Systems, 29(4), 7-62.

Petter, S., \& McLean, E. R. (2009). A meta-analytic assessment of the DeLone and McLean IS success model: An examination of IS success at the individual level. Information \& Management, 46(3), 159-166.

Phang, C. W., Kankanhalli, A., \& Sabherwal, R. (2009). Usability and sociability in online communities: A comparative study of knowledge seeking and contribution. Journal of the Association for Information Systems, 10(10), 2.

Pitt, L. F., Watson, R. T., \& Kavan, C. B. (1995). Service quality: a measure of information systems effectiveness. MIS quarterly, 173-187.

Preece, J. (2000). Online communities: Designing usability and supporting socialbilty: John Wiley \& Sons, Inc.

Rouibah, K. (2008). Social usage of instant messaging by individuals outside the workplace in Kuwait: A structural equation model. Information Technology \& People, 21(1), 34-68.

Scott, M., DeLone, W. H., \& Golden, W. (2011, June). IT quality and egovernment net benefits: a citizen perspective. Paper presented at the European Conference on Information Systems, Helsinki.

Seidman, G. (2013). Self-presentation and belonging on Facebook: How personality influences social media use and motivations. Personality and Individual Differences, 54(3), 402-407.

Shanmugam, M., Sun, S., Amidi, A., Khani, F., \& Khani, F. (2016). The applications of social commerce constructs. International Journal of Information Management, 36(3), 425-432.

Shannon, C. E., \& Weaver, W. (1949). The Mathematical Theory of Communication (Champaign, IL. Urbana: University of Illinois Press.

Shin, H. K., \& Kim, K. K. (2010). Examining identity and organizational citizenship behaviour in computer-mediated communication. Journal of Information Science, 36(1), 114-126.

Simmel, G. (1910). How is society possible? American Journal of Sociology, 16(3), 372-391.

Simmel, G., \& Hughes, E. C. (1949). The sociology of sociability. American Journal of Sociology, 55(3), 254-261.

Sprouse, J. (2011). A validation of Amazon Mechanical Turk for the collection of acceptability judgments in linguistic theory. Behavior research methods, 43(1), 155-167.

Stafford, T. F., Stafford, M. R., \& Schkade, L. L. (2004). Determining uses and gratifications for the Internet. Decision Sciences, 35(2), 259-288.

Tam, J. L. (2004). Customer satisfaction, service quality and perceived value: An integrative model. Journal of marketing management, 20(7-8), 897-917.

Teas, R. K., \& Agarwal, S. (2000). The effects of extrinsic product cues on consumers' perceptions of quality, sacrifice, and value. Journal of the academy of marketing science, 28(2), 278-290.

Van der Heijden, H. (2004). User acceptance of hedonic information systems. MIS quarterly, 695-704.

Venkatesh, V., \& Davis, F. D. (2000). A theoretical extension of the technology acceptance model: Four longitudinal field studies. Management science, 46(2), 186-204.

Verhagen, T., Feldberg, F., van den Hooff, B., Meents, S., \& Merikivi, J. (2011). Satisfaction with virtual worlds: An integrated model of experiential value. Information \& Management, 48(6), 201207.

Wang, L. C., Baker, J., Wagner, J. A., \& Wakefield, K. (2007). Can a retail web site be social? Journal of Marketing, 71(3), 143-157.

Wang, Y. S. (2008). Assessing e-commerce systems success: a respecification and validation of the DeLone and McLean model of IS success. Information Systems Journal, 18(5), 529-557.

$\mathrm{Xu}$, J. D., Benbasat, I., \& Cenfetelli, R. T. (2013). Integrating service quality with system and information quality: An empirical test in the e-service context. MIS quarterly, 37(3).

Yang, Z., \& Peterson, R. T. (2004). Customer perceived value, satisfaction, and loyalty: The role of switching costs. Psychology \& Marketing, 21(10), 799-822.

Yu Su, Y., Than Win, K., Fulcher, J., \& Chia Chiu, H. (2009). Measuring end-users' opinions for establishing a usercentred Electronic Health Record (EHR) system from the perspective of nurses. Journal of theoretical and applied electronic commerce research, 4(2), 55-63.

Zeithaml, V. A. (1988). Consumer perceptions of price, quality, and value: A means-end model and synthesis of evidence. The journal of marketing, 52(3), 2-22.

Zheng, Y., Zhao, K., \& Stylianou, A. (2013). The impacts of information quality and system quality on users' continuance intention in information-exchange virtual communities: An empirical investigation. Decision Support Systems, 56, 513-524. 
Zhou, Z., Fang, Y., Vogel, D. R., Jin, X.-L., \& Zhang, X. (2012). Attracted to or locked in? Predicting continuance intention in social virtual world services. Journal of management information systems, 29(1), 273-306. 